\title{
The Democratic Syllabus
}

Susan McWilliams, Pomona College

ABSTRACT The ideal of the "democratic classroom" has been discussed in educational circles for several years. This article answers the question of whether there are specific advantages to be derived from a democratization of the political science classroom, especially one in which democracy itself is a focus of study. Can giving students more power over course content enhance their understanding of democratic authority and process? The author approached these questions by adding several "democratizing" elements to a seminar course, most notably a "democratic syllabus" in which students determined discussion topics, led class sessions, and submitted work of their own choosing. Student surveys and the author's reflection suggest that the democratic syllabus was a success in terms of the classroom dynamics that it engendered and the thinking about democratic politics and citizenship that it encouraged. Both students and professor agreed that the democratic syllabus presented challenges that should be considered by anyone thinking about creating or modifying a course on this model. Yet this article argues that many political science courses would benefit from similar endeavors in classroom democratization.

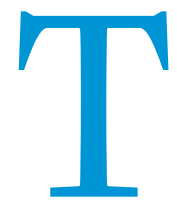

he idea of the "democratic classroom" has been discussed in educational circles for several years, and the general desirability of a classroom in which students are engaged participants rather than passive recipients is well documented (Beyer 1996; McCabe 2010; Pearl and Knight 1999; Wolk 1998). Are there specific advantages to be derived from a democratization of the political science classroom, especially one in which democracy itself is a focus of study? Can that democratization go beyond the typical operations of a discussion-based seminar? Might giving students more power over course content enhance their understanding of democratic authority and democratic process? Is a radical democratization of the political science classroom possible and, if so, what effects does it have on students and what they learn?

In spring 2013, I sought to answer these questions by adding several "democratizing" elements to a seminar course that I regularly teach titled "American Democracy in Theory and Practice." I chose to experiment with this course because its focuscomparing academic treatments of democracy to the lived experience of democracy in America-seemed conducive to such a project. Because students in this course must think about democracy in several dimensions, I was willing to take a risk in democratizing this class; at the least, I figured, the experiment would provide material for course-relevant discussion throughout the semester. In addition, I typically run the course as a small, discussion-based seminar; given that baseline, the prospect of ceding

Susan McWilliams is associate professor of politics at Pomona College. She can be reached at susan.mcwilliams@pomona.edu. to students even more authority over its content seemed like an interesting pedagogical challenge.

For my experiment, I added several features to the course to make it more democratic than most college seminar courses tend to be, creating what I thought of in total as a "democratic syllabus." Three features are the most worth mentioning. First, I allowed for "democratic topic selection." I assigned two weeks' worth of introductory readings but had the students vote on ideas that they wanted to discuss for the remainder of the semester. ${ }^{1}$ Second, I required "democratic discussion leading," which devoted several weeks to student-led discussion on course-relevant topics of their choice. Third, I included "democratic assignments"; that is, the course's required projects were loosely structured in terms of possible topics, approaches, and deadlines.

When the semester ended, I surveyed my students about those features of the course, asking them to reflect at length (and anonymously, if they so chose) about how, if at all, the democratic syllabus affected their experience as students and their thinking about democracy. I also reflected -both during and after the semesterabout how this iteration of the course compared to its more traditional variations, how its structure impacted my teaching, and how this experiment might serve as either a model or a caution for other courses in political science. Ultimately, my students and I deemed the democratic syllabus a great success in terms of both the classroom dynamics that it created and the thinking about democratic politics that it encouraged. Despite the fact that this course demanded more work than any of my other courses, the student evaluations for this iteration of "American Democracy in Theory and Practice" were more laudatory than usual. More than 
a year later, I still hear from graduating seniors that this was the most important course they took in college.

That said, my students and I agreed that the democratic syllabus presented particular challenges and had certain drawbacks that should be considered by anyone thinking about creating or modifying a course on this model. It also is important that for various structural reasons, our experience may not be able to be translated to all or even most college classrooms. Therefore, after describing the experiment in detail, I reflect more broadly about the generalizability of the democratic syllabus in political science teaching. power professors usually have, just by virtue of their position as syllabus-designers. Similarly, two students reminded me that although this syllabus was far more student-generated than most, calling it democratic was "overstated" because "ultimately, the professor chose the direction that each topic went" and "it was really still largely structured" by a professorial authority. 5

The direction of these comments suggests ways in which, throughout the semester, democratic topic selection gave me opportunities to talk about the difficulties of basically democratic governance. For instance, on the first day, my shocked students expressed anxiety that they might be "choosing wrong" by choosing

\section{More than a year later, I still hear from graduating seniors that this was the most important course they took in college.}

\section{DEMOCRATIC TOPIC SELECTION}

On the first day of class, my students were shocked when I presented them with an almost blank syllabus and a survey. I explained that after a two-week introductory period, during which we would read several works that address the general idea and practice of democracy in America, the course would have five two-week-long, topic-related sections, the subjects of which would be determined by student vote. They were offered a choice of 22 subject areas (for each, I also listed the types of questions that we might discuss in class). ${ }^{2}$ After the votes were counted, I selected readings for each topic and filled in the syllabus. In several instances, students suggested articles, books, and videos that they thought would stimulate excellent discussion on a particular topic.

Without exception, the students praised this feature of the course. Their comments almost all concerned two points. First, they reported that voting on the discussion topics "increased student interest" and made them more "invested" in their coursework. Because "we were already interested in the topics we were discussing," one student commented, "we were more passionate about the readings and work." Said another, "I think this led to a more engaged and thoughtful class" because "students actually chose the topics and questions we discussed. There wasn't a single class where I felt like we were talking about something that didn't matter." (Another student made the same point in a particularly blunt and charming way: "Given that we had input into the specifics of conversation, if it wasn't interesting or if conversation sucked, [we knew] it was ultimately our fault," he wrote.3)

Second, the students emphasized that being able to vote on the topics discussed increased their sense of camaraderie. As one wrote, this aspect of the democratic syllabus "created a much more communal atmosphere conducive to discussion" because "all of us knew we were talking about these things because we wanted to." It "contributed to a sense of community between us," said another.4

It is interesting that most of my students also framed their comments about this aspect of the course in terms of the politics of education. "It made me realize the importance of student responsibility and flexibility in curricular goals for a quality education," said one. "Students have to feel that they have an equal part in their educational process for them to truly contribute." Wrote another, "It reinforced my ideas about how important relationships and community are to learning." Many wrote that the course made them see for the first time how much the topics rather than having the professor choose for them. I used the opportunity to discuss with them the ways in which self-government in practice can be difficult and unsettling, even when we value the concept of self-government in the abstract. We talked about how the exercise of choosing topics illustrated how democratic governance results in outcomes that are relatively popular but not necessarily in outcomes that are correct. I spoke with them about the many political thinkers, from Alexis de Tocqueville to James Baldwin, who connected democratic governance to feelings of internal anxiety; their experience, it became clear, was emblematic of bigger issues.

\section{DEMOCRATIC DISCUSSION LEADING}

Another feature of the democratic syllabus was that near the end of the semester, we devoted two weeks to student-led discussion. Each student was given half of a class session to lead a discussion based on readings and questions of his or her own choosing. In those sessions, I participated as a student, limiting myself to one question or comment every 20 minutes.

Regarding this aspect of the course, students' comments also were almost uniformly positive. "The discussions were among the best ones we had," said one. "Student-led discussion at the end of the semester helped to change discussion dynamics and power structures," wrote another. Many opined that they enjoyed the role of discussion leader-as one student put it, because "being able to choose any topic I wanted to and having class time to talk about it was really cool."6

Yet most of them pointed out that the success in this course should not be taken as a blanket endorsement of student-led discussion. (I, having had my own share of negative experiences with student-led discussions, would agree.) For their part, the students emphasized that they would not have enjoyed or learned from this exercise in even slightly different circumstances. A few mentioned, for instance, that it was important for student-led discussions to occur at the end of the semester, "when we had substantial practice discussing as a group." Others said that this exercise worked-several specified that it worked better than in other courses-because of the context of the democratic syllabus and their unusual sense of course ownership. "For this to work, the students must be intellectually motivated and enthusiastic," one student commented. "It was better than in most classes, where you 'teach' something...you hardly know," reported another.7 
Part of what was interesting about the student-led discussions is that many of them focused on the dynamics underlying of-the-moment campus controversies and local politics. That was encouraging to me in that I could see my students testing the abstract literatures of political science and political theory on the terrain of their daily life. Whereas I perceived this as a critical moment of intellectual connection, my students were happy to hear one another speak intelligently about matters of personal importance. "The students in these classes were more interested and engaged than in any other classes I've taken," wrote one student. ${ }^{8}$

\section{DEMOCRATIC ASSIGNMENTS}

The third experimental piece of the syllabus was a plan of democratic assignments. I required my students to complete two tracks of work outside of class. For the first assignment track, "Democratic Observation," I provided a list of approximately 100 sites that political scientists claim are potentially important to democratic practice in the United States. 9 Throughout the semester, they had to visit five sites and write a two-page reflection about each experience. For the second assignment track, each student chose to undertake either a "Democratic Expression" or a "Democratic Understanding" project. The former project entailed developing a plan for expressing a public position or educating American citizens on an issue and then executing that plan, reflecting on the experience in writing. The latter required the students to design and execute a research project to explore how a particular issue plays out or is experienced in a particular community. For both assignments, I gave the students wide latitude about when and how they completed their work, emphasizing that independent thought would be rewarded.

Despite initial misgivings about having such wide latitude, the students all concluded that this freedom had been a positive experience. "At first, I wasn't sure exactly how this all would work out," said one, "but I found that being given greater flexibility was a fantastic idea once I got ideas for exactly what I'd do." Independently of one other another, the majority said that the loosely structured assignments encouraged creative thinking. One student commented, "I think that this component allowed us to challenge ourselves to think outside the box and apply what we learned creatively." Opined another, "The loose structure definitely helped promote creativity and inspired me to do things I was really interested in." A third wrote, "I usually just navigate by deadlines and grading criteria, so this forced me to take more initiative and think more deeply about what I would do and what I would write about it. With so many possibilities, I felt pressure to do really creative things." 10 that he saw as representative of the obligations of democratic self-governance. A third wrote, "I think the nature of the assignments expanded the spheres in which I can see the intersections between democracy and public/private life." ${ }_{11}$ Here, too, my students reported that the democratic syllabus inspired them to think about the nature of democratic politics in ways that they had not done before.

\section{CONCLUSION}

Without question, I believe that the democratic syllabus in my "American Democracy in Theory and Practice" class was a success. (Note: While writing this article, I was concerned that readers may think I "cherry-picked" positive comments from the student surveys. I want to emphasize that I included quotations from every student and which are representative of the surveys at large. The students praised this course in a way that was unparalleled in my experience.) I plan to teach the course this way again mostly because my students were so enthusiastic about the experience- "if other students don't get this chance, I would quite literally cry," one wrote-and so uniform in reporting that the democratic syllabus helped them to think better about the idea and practice of democracy. "Teaching this way," said one, "gives students an experiential exposure to democracy outside of its usual environment and gives them agency in the classroom." Another put it more personally, writing, "The course really taught me a lot about my place as a citizen in a democracy, and society in general." ${ }_{12}$ I also enjoyed the energy and engagement that marked this course: I think that students in this version of the course learned more in general and more about democratic governance in particular than those who have took the more traditional version.

That said, my students and I are uncertain about the generalizability of our semester-long experiment. The course worked largely because it was a small-scale seminar, with only eight students. They emphasized the importance of this small scale in their reflections. It was "the small size most of all," wrote one, that gave everyone "an equal opportunity to speak and be heard" in a democratic mode. "I think it's really only possible to achieve these things when you have a small enough scale," said another. Notably, and echoing the ancients, about half of my students opined that the size of the course convinced them that democratic governance is best realized on a small scale. "There is a capacity for the democratic shaping of this course to reflect broader democratic trends, and one which repeatedly came up was the issue of scale," said one student. Another affirmed that the course "made me realize just how much democracy depends on scale and who is participating." ${ }_{13}$ My own sense is that although I am certain that clickers

\section{Here, too, my students reported that the democratic syllabus inspired them to think about the nature of democratic politics in ways that they had not done before.}

Calling this his "favorite part of the course," one student summarized a widely shared sentiment by saying, "I thought it encouraged an organic approach to experiencing life in the context of a democratic society." Another commented that realizing that "we could get as little or as much out of it as we put in" placed "accountability and responsibility on the individual" and other technologies could be marshaled to allow a large class to vote on many questions, such a class would and could not be as profound an experience. In my judgment, a seminar with more than 16 students would dilute the efficacy of the democratic syllabus as described here. More generally, the success of this experiment reaffirms my sense that the most productive learning 
happens in small, intensely personal classrooms-which are not the norm in contemporary universities.

With one exception, I ran this course with students who were in at least their fourth semester of college. Most had previous coursework in American government and/or political theory-which, from my perspective, was a boon. Yet, at least some students said that they would have appreciated this type of classroom experience earlier in college. One student suggested that our college's general introductory seminar should be reconfigured on the democratic-syllabus model so that freshmen would be able reflect on their responsibilities as students and citizens before doing other coursework.14

Finally, it is important to mention that teaching a course with a democratic syllabus requires substantial work before and throughout the semester. Although I had two paid student assistants to help administer the class, I spent about four times as much time as usual in running it. For instance, to provide a list of topics, I had to ensure that any five topics the students chose would result in a coherent course. In turn, that meant that I had to imagine dozens of variations of the syllabus, only one of which would come to fruition. After the students chose topics, I had to quickly select and order readings. I consulted at length with each of my students as they developed and crafted their projects. The irony that running a more "democratic" course was significantly more work for the professor was not lost on me; my consolation was remembering that the course also required more of my students-a fact reflective of the truth that democratic politics involves time and effort on the part of all concerned. A teacher interested in adopting any variation on this model should not imagine that democratizing the syllabus results in a lighter workload.

Yet given the hugely positive results of this experiment with a democratic syllabus, I recommend that others try similar experimentation of their own-even if, for any reason, they cannot entirely copy this model. Finding experiential ways to help students think more intensely about politics in general and democratic politics in particular, I argue, enhances our capacity not only as educators in political science but also as educators of the public.

\section{ACKNOWLEDGMENTS}

Neither this article nor the successful class described would have been possible without the talent, generosity, and enthusiasm of my students in the spring 2013 "American Democracy in Theory and Practice" course: Nigel Brady, Rachel Keyser, Graham Rowe, Kyle Schneider, Jack Shaked, Lucas Tamminen, Daniel Tan, and Kevin Tidmarsh. I also thank my student assistants, Lena Connor and Trevor Smith.

\section{NOTES}

1. The introductory readings focused on two questions: (1) How should we think about studying democracy in America? and (2) What are the broad dimensions and challenges of democracy in America? The readings included selections from G. K. Chesterton's What I Saw in America, John Dewey's "Creative Democracy," Alexis de Tocqueville's Democracy in America, and Sheldon Wolin's "Fugitive Democracy." I also required the students to read David Glenn's reflection on experimental fieldwork in political science, "Political Scientists Get Their Hands Dirty" (The Chronicle of Higher Education, September 21, 2009).

2. The topics included the arts, business, children and the elderly, civic engagement class, crime and punishment, diversity and inequality, education, family, food and agriculture, immigration, media, religion, representation, scale and federalism, race, sex and gender, sports, technology, transportation, urban/suburban/rura communities, and name your own topic. The five sections that the students selected were crime and punishment, diversity and inequality, education, religion, and scale and federalism.

3. GR, LT, KT, NB.

4. NB, RK.

5. JS, DT, RK, GR, KS.

6. KT, KS, LT.

7. RK, GR.

8. RK.

9. The list loosely followed the topics that the students selected for in-class discussion - with, for instance, sites related to religion (e.g., megachurch, mosque, and synagogue); education (e.g., community college, homeschool association event, and public kindergarten); crime and punishment (e.g., criminal courtroom, jail, and police station); and so on.

10. KT, JS, RK, LT.

11. DT, NB, RK.

12. NB, JS, KT.

13. LT, RK, NB, KT.

14. KT.

\section{REFERENCES}

Beyer, Landon E. (ed.). 1996. Creating Democratic Classrooms: The Struggle to Integrate Theory and Practice. New York: Teachers College Press.

McCabe, David S. 2010. Towards a More Perfect Union: Creating Democratic Classroom Communities. Dubuque, IA: Kendall Hunt.

Pearl, Arthur, and Tony Knight. 1999. The Democratic Classroom: Theory to Inform Practice. New York: Hampton Press.

Wolk, Steven. 1998. A Democratic Classroom. Portsmouth, NH: Heinemann. 